\title{
6. The Media and the Guide to the Basin Plan
}

\author{
Åsa Wahlquist
}

The current over-allocated state of the Murray-Darling Basin, and the consequent run-down in its environmental health, is due to more than a century of parochial decisions - decisions typically taken with no regard for downstream users, the Basin as a whole, or the health of the environment. The Water Act 2007 aims to redress the balance, to restore the environment and to bring about a huge cultural change in managing the waters of the Basin. The Act received bipartisan political support when it was passed by the Federal Government.

Under the Act, the Murray-Darling Basin Authority (MDBA) must prepare a Basin Plan, reallocating the water in the Basin to provide environmental watering, in accordance with international environmental agreements (Commonwealth of Australia 2007).

The process outlined in the Act is essentially a top-down approach: while the MDBA must consult with the basin States, Basin Officials Committee and Basin Community Committee in preparing the plan, no specific mention is made of public consultation.

This stands in stark contrast with the European Union's approach through the 1998 Aarhus Convention. The United Nations Economic Commission for Europe describes it as a 'new kind of environmental agreement', which links environmental rights and human rights. It acknowledges the obligations to future generations, states that 'sustainable development can be achieved only through the involvement of all stakeholders', commits governments to accountability and 'focuses on interactions between the public and public authorities in a democratic context' (UNECE 1998).

Any process of cultural change and of communication involves the media. But reporting on the Basin Plan - and indeed on the ongoing story of managing the waters of the Murray-Darling Basin-is an overwhelming challenge. It is a complex story, but the media is increasingly dominated by the 24-hour news cycle. It is moving towards shorter and shorter radio and television grabs, towards news items brief enough to be read on mobile devices.

The Basin Plan was a long time in gestation. Although several interviews were granted in the early stages, the MDBA remained silent in the months leading up to the release of the Guide to the proposed Basin Plan (MDBA 2010a). 
The Authority chose to break its silence on the release of the Guide. It set up a 'lock-up' for journalists and interested parties, similar to that used by the Treasury on the release of the annual budget. Journalists - stripped of their phones and communication devices - were allowed to read the report several hours before the release time: 4 pm on Friday, 8 October 2010.

There was a lot of reading and not much time. The Guide is 260 pages long, supported by 21 documents and the Basin Plan Knowledge and Information Directory of about 1000 reports that identifies information and knowledge, including scientific and socioeconomic, that underpins the development of the proposed Basin Plan (MDBA 2010a).

Just before the release, veteran journalist and media commentator Margaret Simons made an unprecedented plea on the web site Crikey. In a piece headlined 'It's the story of a generation, shape up, media', Simons (2010) wrote: 'Today we have one of the biggest stories in the nation's history. And it isn't even on the front page of most of today's newspapers, nor is it heading many news bulletins. I can hardly believe it.'

Simons, who has lived on and written about the Murray River, pointed out:

The plan, two years in the making, is the result of the first exercise ever in asking the vital question: what is sustainable use of this nation's major river system? It has been an immense research undertaking. And we knew, or should have known, that the answer would be 'something very different to what we are doing now'. But how do we deal with that - with the human suffering, the wholesale changes to land use, the unequal distribution of punishment for 200 years of mismanagement and ignorance and political stuff-ups and lack of will? This is a story about fairness... This is a story about how we exist in this nation. It is about history and the future. It is a landmark moment in our nation's history. (Simons 2010)

Simons ended with a plea to her colleagues: 'Get across the issue. Do better when the plan is released. This is one story that is not spectator sport. This is that rare thing - a story that really matters, and where our reporting can make a real difference' (Simons 2010).

The day after the release of the Guide, the banner headlines on the front page of Sydney's biggest-selling Saturday newspaper (Roy Morgan 2010), the Daily Telegraph, read 'Knockout blow', subtitled 'Huge power bills, now soaring food prices' (Rolfe 2010).

The article asserted that the Murray-Darling Basin Plan would slash water allocations and 'inflate the price of vegetables, fruit and even clothing'. Inside 
articles were titled 'Blood from stone, river study puts environment ahead of food output' (Farr and Townsend 2010), and 'Stopping the flow would finish Glen' (Townsend 2010) (Glen referred to Griffith rice grower Glen Andreazza, who earlier in the year celebrated a record rice crop of 11 tonnes to the hectare).

The national broadsheet, The Australian, titled its front-page story 'Reality hits in Murray blueprint'. The article began: 'Restrictions on water use along Australia's biggest river system could wipe out 16 per cent of the irrigated agriculture industry - worth up to $\$ 1$ billion a year - and have severe social and economic impacts on rural communities in the nation's foodbowl' (Franklin and Karvelas 2010).

The 'reality hits' was presumably written without irony, though it followed several days of front-page stories in that broadsheet detailing mounting farmer and basin community alarm. In remaining silent until the Guide was released, the MDBA relinquished the public platform to those who had most to fear from changes in water allocation. It effectively allowed irrigator groups and river towns to set the agenda, and in the following months the Authority was unable to regain control of the agenda.

On the day of the Guide's release, The Australian ran a page-one story titled "Huge cost" in returning water to Murray'. It stated that 'tens of thousands of jobs' would be lost in rural communities (Wilson and Schliebs 2010). Two days before the release of the Guide, the front-page story-headlined 'Farmers fume over Murray-Darling cuts' — stated between 3000 and 4000 gigalitres 'would be taken away from irrigators and added to water already quarantined for environmental flows' (Owen and Schliebs 2010).

On the day after the release, The Australian ran nine stories about the Basin Plan over two pages. They included 'Plan will "save river, kill towns"' (Vasek and Wilson 2010), 'Rice, cotton farmers hardest hit' (Karvelas 2010), and 'Farmers say jobs will flow out with water' (Akerman 2010). All up, nearly 5000 words were printed in that edition on the topic. But just more than 600 words were devoted to the aim of the Plan: to restore the health of the Murray-Darling system. It was left to the environment editor, Graham Lloyd, in a comment piece, to point out: 'Environmentally, the starting point of yesterday's report by the MurrayDarling Basin Authority that the river mouth remain open at least 90 per cent of the times is a good one.' He went on to opine: 'It is unfortunate that a long history of failure by state governments in over-allocating water entitlements has pitted the interests of irrigators against those of the health of the river basin' (Lloyd 2010). 
The Sydney Morning Herald's Saturday page-one story was titled 'Selling the farm to save the rivers' (Arup 2010). Inside, it ran a spread with six stories and a large map of the Basin on which, incredibly, every single catchment was misnamed (SMH 2010a).

The paper counterpointed 'Redgum skeletons are stark, eerie sentinels' (Jopson 2010) - a plea from a farmer for more environmental water - with a comment piece by long-time rural writer Paul Myers, 'You can't pay to save the environment if rains fail', which argued the problem was a decade of record low rainfall. He asserted that dams 'would eliminate the claimed need for irrigation water cuts and make more water available to grow food' (Myers 2010).

It was left to the Sydney Morning Herald's editorial to lay out the case for the Basin Plan: 'We can see that if the government proceeds with the plan-as it should - it will be tough going... The problem is no longer that an entire river basin is dying. The problem has suddenly become the government's plan to revive it' (SMH 2010b).

Australia's largest-selling paper, Melbourne's Herald Sun, posted an article titled 'Farmers pay high price to save Murray-Darling Basin', which ran fourteenth on its web page after articles about a cat needing a home and cricketer Shane Warne being 'king of the tweets' (Harvey 2010).

Melbourne's The Age took a different tack, with its lead article on the Plan titled 'Murray-Darling set for minimum water return', though the subtitle was the by now predictable 'Farmers hit under Murray plan' (Ker and Arup 2010).

It was left to South Australia's The Advertiser to remind readers that the Basin Plan aims to restore the degraded river system. The Advertiser has conducted a long campaign to restore the Lower Lakes and save the Murray River (see $<$ www.adelaidenow.com.au/news/in-depth/save-the-murray $>$ ). Its Saturdaymorning headline read 'River rescued but at a cost'. The article, predictably, went on to lament 'our irrigators are facing cuts even greater than those faced by irrigators and other rural industries upstream' (Kelton 2010).

The Australian Financial Review ran three news stories the day after the Guide was released, leading off with a page-three story: 'Water cuts to cost 800 jobs, $\$ 1$ bn at farm gate' (Morris 2010b). It also ran a comment piece-'Debate heats up in fluid environment' - in which journalist Sophie Morris argued the postelection climate had 'recast the debate, elevating regional issues but also giving the Greens a bigger voice'.

She wrote: And if there are significant reforms...it remains to be seen whether they will eventually be enforced' (Morris 2010a). 
The headlines of just that one day are deeply revealing. They reflect the different State and essentially city-based interests of the metropolitan media. They largely emphasised the personal case story of the irrigator facing cuts, the town facing job losses, and the overall forecast economic losses. They pointed to the political debate that threatened to overwhelm a reasoned assessment of the Basin Plan.

While television news items are necessarily brief, the Australian Broadcasting Corporation $(\mathrm{ABC})$ provided the most thorough coverage. Just two hours after the Guide was released, ABC Radio National's The National Interest program tackled the Plan. ABC TV's Lateline dealt with the topic the same day.

Both The National Interest and Lateline went live to air. That gave the commentators, and in the case of Lateline, the Water Minister, Tony Burke, the opportunity to make their cases unedited.

On The National Interest, Australian Farm Institute Executive Director, Mick Keogh, explained it was important to understand that the Basin Plan was drafted in accordance with the requirements of the Water Act 2007, which was legislated by the Howard Government, and passed by both sides of politics:

The legislation tells it what it can and can't do. That is where the problem lies... They have to restore the basin to what is called an environmentally sustainable level of take. That means they have to first and foremost make some judgement about how much extra water is needed to restore the environment, and then after they have done that, they are allowed to look at what the best way is to use the rest of the water to maximise social and economic outcomes. There is no doubt that legislation gives them a very narrow focus. (Keogh in ABC 2010a)

On Lateline, Water Minister, Tony Burke, stressed that the Guide to the proposed Plan was just that: 'This is not the Basin plan. It is a Guide to a draft. This is just the beginning of a major round of consultations' (ABC 2010b).

The Guide was originally scheduled for released in July. It was postponed until August, but that date fell within the election campaign, and the MDBA decided to further postpone the release until after the election. Minister Burke rebuffed the suggestion politics had a role in the timing of the release of the Guide: 'They [the MDBA] are truly an independent authority and any minister who tried to treat them as anything other than that would be in for a pretty big shock' (ABC 2010b).

Two days later, on Australian Agenda on Sky News, Minister Burke again stressed the point: 
People are referring to it as "the basin plan". It's not. It's a guide to a draft document. It won't be until the end of next year that we actually have a basin plan that has to be signed off by me and then needs to maintain the confidence of each house of Parliament, because either house of Parliament can vote it down once it's put in place...

The last thing I' $m$ going to do is start giving instructions to an independent authority from the sidelines. This authority was given its independence by the Howard Government and given it for good reasons. The MurrayDarling Basin has been plagued by being managed as though it were different river systems that all followed state boundaries. That's part of how we got to the problems that we're in now. (Burke 2010)

The $\mathrm{ABC}$ also put together a web site that not only pulled together most of the ABC's coverage of the Plan, it also provided essential background ( $<$ www.abc. net.au/rural/murraydarling/>).

Some media outlets, such as the ABC, had long covered the Murray-Darling. Others, such as The Advertiser and The Australian, had actually conducted campaigns to save the Murray. ${ }^{1}$ In its editorial on Monday, 11 October 2010, The Australian called the Guide 'a landmark in water policy'. It stated: 'The Australian feels strongly about the issue. In 2001, we launched a Saving the Murray campaign...it helped kick off the process that led to this report' (The Australian 2010).

The editorial noted that the Government could draw on 'a history of bipartisan support for reclaiming water but navigating the interests of South Australia, Victoria, NSW and Queensland will not be easy'. It pointed out that more work was needed on the economic impact, the job losses and the cost of the buyback. The editorial went on to state: 'There is no disputing the damage inflicted on the system, which has been under extreme stress from drought as well as water over-allocation.' It concluded: 'The authority's report is an important step in developing the sustainable solution that has eluded politicians on both sides for decades' (The Australian 2010).

News reports might be the first draft of history, but their obsession with the immediate, with the breaking news story, is too frequently at the expense of history. Most journalists are non-specialists grappling with unfamiliar topics, pressed for time, striving to render the complex into a news story with a 500word limit.

1 Disclaimer: the author participated in The Australian's 'Saving the Murray' campaign as that paper's rural writer. 
The Guide is 260 pages long. It provided a helpful and comprehensive history of the development of the Murray-Darling Basin, a wealth of information on the Basin itself, the role of the MDBA and the objectives of the proposed Plan.

The lock-up before the release of the Guide not only gave journalists time to read it before reporting on it, it also enabled key players to address journalists, and answer their questions.

As one unnamed journalist said plaintively at the Guide release press conference with MDBA Chairman, Mike Taylor: 'we don't have the 300 pages to write about it in our newspapers or television stations...can we make the comments as simple as [possible]... because it is getting quite complex' (Media Monitors 2010).

The MDBA was already having to play catch-up when the Guide was released. The irrigators and river towns had already set the agenda, and the Authority was forced to respond to their claims.

There were a number of strong, newsworthy points that the MDBA either failed to make or failed to interest the media in.

In the same week that the Australian media was celebrating records set at the Commonwealth Games, it overlooked a major home-grown first.

Chairman, Mike Taylor, told journalists

to plan a basin in the way that is being proposed is really a world first... So it is very much an extraordinary thing, not only in an Australian context, but in an international context.

I think it is clearly the forerunner... of how nations around the world are going to need to deal with water resources. It [water] is the scarcest resource that confronts the world, and communities, going into this century. (Media Monitors 2010)

The huge amount of work involved in preparing the Basin Plan was also overlooked. The Guide stated: 'The task of assessing Basin-wide and catchment specific environmental water requirements has never before been undertaken in the Murray-Darling Basin' (MDBA 2010a:58). Nor had key environmental assets been identified or prioritised, the water needs of key ecosystem functions had not been considered at the Basin scale, and 'very little work had been done to define the productive base and identify key environmental outcomes at the Basin scale. In short, this is largely new territory for the Basin' (MDBA 2010a).

Another key point overlooked by most journalists was how prescriptive the legislation governing the process is. MDBA Chairman, Mike Taylor, told the gathered journalists that the Water Act 
sets down a prescription by which the Basin Plan must be established. It requires the Authority to, first of all, identify key ecosystems and key environmental assets, to determine the water requirement that is necessary to both maintain and restore those assets and to not compromise them.

In doing so, the Act asks the Authority to identify the amount of water that's needed for those assets, and consequently to reduce the amount of water that is available for existing human and irrigation purposes. So this Act leads to some very major changes. (Media Monitors 2010).

Section 20 of the Water Act 2007 spells out the purpose of the Basin Plan. That purpose, it states, is 'to provide for the integrated management of the Basin water resources' by providing for 'the establishment and enforcement of environmentally sustainable limits on the quantities of surface water and ground water that may be taken from the Basin water resources (including by interception activities)'. That use, it states, must be in a way that 'optimises economic, social and environmental outcomes' and enables water 'to reach its most productive use through the development of an efficient water trading regime across the Murray-Darling Basin' (Water Act 2007, <www.austlii.edu. au/au/legis/cth/consol_act/wa200783/index.html>).

Taylor told the journalists: 'Interestingly, the Act itself does not deal with... agriculture, food or fibre production. The parliament very much focussed on laying down this process by how we would readdress the environmental issues.' He added that the Act also required the MDBA use 'the best available science, and failing that the precautionary principle'.

He went on to stress the importance of addressing the social and economic aspects of the proposed Plan, through a long process of consultation:

We look forward to working very, very closely with communities, environmental groups, industry groups, local governments, state governments, [the] federal government, and other parties in making sure not only is the data, the modelling, the information which we've based this on fully tested, but also that the conclusions are properly evaluated. (Media Monitors 2010)

Also largely overlooked was the fact the MDBA actually opted for the lower end of the recommended water return, and the consequences of this decision for some catchments in the Basin.

As Taylor told the journalists: 'The reason we drew the line at 4000 [GL was that the] social and economic impacts are going to be very significant.' 
An additional 3000 GL per year would mean the Border and Lachlan Rivers would retain a moderate rating for environmental health outcomes; the Murrumbidgee, Campaspe, Goulburn-Broken, Barwon-Darling and WimmeraAvoca rivers would move from poor to moderate; while the Condamine-Balonne, Gwydir, Loddon, Lower Darling and Murray rivers regions would retain their 'poor' ranking.

An additional $4000 \mathrm{GL} / \mathrm{yr}$ would raise the Condamine-Balonne, Loddon and Murray rivers to moderate, while the Gwydir and the Lower Darling rivers would remain poor (MDBA 2010a:74, 112).

The MDBA stated that $3000 \mathrm{GL}$ was the minimum 'required to achieve the environmental objects of the Water Act'. But it did point out: 'This level of reduction has a high dependence on a long-term return to wetter climatic conditions across the Basin.'

This could be a doomed hope, with the MDBA stating earlier in the Guide: 'the latest climate change modelling suggests that, under a median 2030 prediction, conditions are likely to be around 10\% drier than past experience' (MDBA 2010a:36).

In fact it is only with a long-term average increase of $7600 \mathrm{GL} / \mathrm{yr}$ that the environmental targets are all met and all catchments improve from their existing status to good flow levels' (MDBA 2010a:74).

But the MDBA (2010a:82) considered the impact of taking 7600 GL from irrigation too severe: 'the Authority has judged that in order to optimise social, economic and environmental outcomes, as it is obliged to do under the Water Act 2007, it can only consider Basin-wide reductions of between 3000 and $4000 \mathrm{GL} / \mathrm{yr}$ (reductions of $22-29 \%$ of current diversion limits).' As a result, it considered three scenarios - an increase in the water available to the environment of: 3000 GL/yr, $3500 \mathrm{GL} / \mathrm{yr}$ and $4000 \mathrm{GL} / \mathrm{yr}$.

By 30 September 2010 - a week before the Guide was released - the Federal Government's water buyback had purchased 920 GL, or between nearly onethird and one-quarter of the proposed targets (Department of Sustainability, Environment, Water, Population and Communities 2008). Despite Taylor mentioning the buyback figure several times, this progress was also largely overlooked in the press coverage.

A number of media reports, however, raised the spectre of threats to food security, but these fears do not stand up to scrutiny. In March 2010, the Productivity Commission prepared a report on the market mechanisms for recovering water. It briefly addressed the question of food security: 'At present, Australia exports around 60 per cent of all of its agricultural output in addition to providing the large majority of the food eaten by Australians' (Productivity Commission 2010:140). 
The Commission stated that 'food production will continue to be influenced by price signals, including those resulting from a decline in water availability'. It concluded that Australia's food security was very unlikely to be significantly influenced by the buybacks then under way.

Since 2006, water allocations in the Murray-Darling Basin have been slashed due to drought. Former Water Minister Penny Wong, in June 2009, told the Victorian Farmers' Federation: 'In the last three years the yield on Basin water entitlements has averaged 2,500 GL per year compared to a long term average of almost 8,000 GL' (Wong 2009). In other words, despite more severe reductions than those proposed under the Basin Plan, Australia's food security was never in doubt.

News focuses on the immediate, the short term. In the months before the Guide was released, the drought that had gripped the Basin since 2002 eased. The media ran a multitude of stories about farmers rejoicing in the best season for years.

In the first week of September - the month before the Guide was released - 1090 GL flowed into the Murray River, which was more than had entered for the entire water year of 2006-07 (MDBA 2010c).

That month was the wettest September since 1993 along the Murray River, and the inflow into the Murray for September totalled $2920 \mathrm{GL}$ - well above the long-term September average of 1605 GL (MDBA 2010d).

The day before the release of the Guide, Water Minister, Tony Burke, flew over the River Murray mouth. The mouth had been kept open by dredging for the past four years, but the good rains that had fallen upstream were at last sufficient for the river to flow naturally to the sea (Wilson and Schliebs 2010).

In the short term of the news cycle, the drought had receded and with it the immediate crisis in the Basin. It was left to the Guide to spell out the dire straits the Basin was still in:

The environment has not had sufficient water for decades. This has led to serious environmental decline in many parts of the Basin. The real possibility of environmental failure now threatens the long-term economic and social viability of many industries and the...strength of many communities.

If the focus does not swing back towards considering water required for the environment, then the nation risks irretrievably damaging the attributes of the Basin that enable it to be so productive. (MDBA 2010a:xiv) 
This fact - the most salient of all: that the very survival of the communities relied on a healthy river system - was the most overlooked of all in the media's coverage of the proposed Basin Plan.

Margaret Simons said her impression of the coverage was that some journalists realised for the first time the importance of the Basin, 'but there was a scramble to "go bush" without any realisation of the complexity and variability of the picture in different regions. For example, how Griffith varies from Renmark, and Forbes from St George.'

She also noted that the only way many journalists could understand the story was in terms of its implications for politics in Canberra: 'That is, whether or not it would be bad for Gillard, whether or not she would have "won" the election if the Murray-Darling Report had been released during the campaign, and so on and so forth.'

Simons noted there were some

honourable exceptions and notable efforts, but on the whole, the media seemed unable to cope with the scale of the story, or its historical context and future implications. I didn't see a single outlet give it the scale of coverage I think it deserves - which is front page news consistently over a long period, supported by major analytical effort, journalistic depth, local presence and diversity of opinion. (Margaret Simons, Personal communication, 13 October 2010)

As the members of the MDBA conducted often boisterous meetings about the Guide, the Basin was finally receiving drought-ending rains. The rains began in July, then pelted down in November and December, running off the saturated catchments into the rivers.

According to the National Climate Centre (2011), spring 2010 was the wettest on record in the Basin and December 2010 was the second-wettest December on record. The resulting inflows into the Murray set a new December record of 2976 GL-well above the long-term average inflow of 420 GL (MDBA 2011). There were floods in south-east Queensland, in the Murrumbidgee, Lachlan and Castlereagh river catchments in New South Wales and in large parts of northern and western Victoria.

By early December, the River Murray was rising, with $48000 \mathrm{ML}$ flowing out the Murray mouth every day, and dredging ceased for the first time in more than eight years (Todd 2010).

On 7 December, MDBA Chairman, Mike Taylor, surprised observers when he announced his resignation. In a statement issued by the MDBA, Taylor said: 
Balancing the requirements of the Water Act 2007 against the potential social and economic impact on communities will be a significant challenge...the Authority has sought, and obtained, further confirmation that it cannot compromise the minimum level of water required to restore the system's environment on social or economic grounds. (MDBA 2010b)

'A sustainable plan for the Basin would require far more than a decision by the Authority on how much water should be transferred from human uses to the environment', he said in his resignation statement, adding: 'I believe it is time for the Government to reconsider the next phase.'

His resignation was widely interpreted by the media as not only challenging the Government's interpretation of the Water Act, but threatening the progress of the Basin Plan.

Adelaide's The Advertiser reported that Taylor's departure increased

the likelihood the authority will shift to a more pro-irrigation stance at the expense of the Lower Lakes and downstream users.

Mr Taylor's departure was a direct response to Government pressure to force the authority to take so-called 'social' and 'economic' factors into account, which the Authority believes it does not have the power to consider under the Water Act.

The resignation was merely the latest setback in the political minefield that is basin reform and suggests that the needs of downstream users and the environment will continue to come a poor second to politically powerful irrigators higher in the basin. (Kenny 2010)

The Prime Minister, Julia Gillard, reportedly held firm: 'I can say to you very clearly that the election commitment I made is that the Government will do what is necessary to implement the Murray-Darling Basin plan' (Kelly and Massola 2010).

She reiterated that the Government's position was to optimise the environmental, social and economic areas: 'That is the aim of these reforms - to ensure that we've got a healthy river, we've got food production and we've got viable regional communities... The government will continue to see these reforms with optimisation across these three areas' (Kelly and Massola 2010).

But Mick Keogh, Executive Director of the Australian Farm Institute, told The Australian that the MDBA had always felt constrained by the Act because of the environmental requirements, 'in that it put a very high level of focus on environmental requirements and then only allowed consideration of socioeconomic factors, subject to having met those environmental requirements or standard' (Kelly and Massola 2010). 
Reporter Alexandra Kirk stated on ABC Radio's PM program: ‘Today Mr Taylor tendered his resignation stating the Authority had sought and obtained further confirmation that it cannot compromise the minimum level of water needed to restore the river system's environment' (Kirk 2010). Heavy rains and flooding through December and into January prompted increased calls for the Basin Plan to be dropped, or at least delayed. National Farmers' Federation President, Jock Laurie, said the strong flows in the river 'buys the government time to sit back and make sure they get this right' (Wilson 2011).

But Prime Minister, Julia Gillard, remained firm:

Rather than just wait until the next drought hits the Murray-Darling, now is the time to get it right for the future. So we will continue in 2011 to pursue our reforms through the Murray-Darling Basin Authority... We've got to get this right, we've got to make sure that we've got a healthy river, viable communities, as well as food production along the Murray.' (Wilson 2011)

At the end of January - three days before Taylor's resignation took effect - the Government appointed Craig Knowles as the new MDBA Chairman. Knowles is a former member of the NSW State Labor Government. He held the Natural Resource ministry between 2003 and 2005, and during that period was a member of the Murray-Darling Basin Commission Ministerial Council. He helped negotiate the National Water Initiative (NWI) and introduced Water Sharing Plans covering 80 per cent of water extracted in New South Wales (NSW Office of Water n.d.). According to the NSW Office of Water, the plans establish rules 'for sharing water between the environmental needs of the river or aquifer and water users, and also between different types of water users such as town supply, rural domestic supply, stock watering, industry and irrigation'.

Knowles' appointment was reported as being both a Labor-mates deal and a good choice - often in the same story (Coorey 2011; Kruger 2011).

Sydney's Daily Telegraph reported:

The ex-Labor minister's appointment as chairman of the MurrayDarling Basin Authority sparked immediate cries of 'jobs for the boys' from the federal and state oppositions. NSW irrigators applauded the appointment but said Mr Knowles faced an 'impossible task' trying to boost water levels in the Murray-Darling without big changes to the Water Act. (Lewis 2011)

Knowles was quick to distance himself from Taylor's interpretation of the Water Act: 
I just disagree with Mike Taylor, let's be frank about that. I've delivered on a lot of environmental legislation over the years - in forestry, in natural resource management, native vegetation, water, and all of those international agreements, all of those environmental imperatives are found in every piece of legislation. The Water Act is no different. I am very comfortable that the scope of the legislation, the objectives of the legislation talk about optimising the economic, social and environmental outcomes as plain as day. (Kruger 2011)

In the same report, the Chief Executive of the National Irrigators' Council, Danny O'Brien, wryly pointed out that 'it's not exactly a job you'd give to a mate'. Meanwhile, the South Australians worried a former NSW politician would overlook that State's special needs, with The Advertiser reporting the appointment was greeted with scepticism.

Knowles told The Advertiser: 'South Australia has much to be concerned about... [But] I'm very comfortable knowing that South Australia has got particular needs and particular imperatives and they are very, very front and centre' (Martin 2011).

There was widespread agreement that Knowles came to the job at a difficult time. His task was to take on a plan that had been very poorly communicated, and that lacked both strong community and political support.

The Guide outlined a Basin Plan for audacious change. The need to cut water allocations in favour of the environment had been obvious for decades - the difficulty had been finding the political will. Although the States - which were responsible for the over-allocation - had made incremental cuts, it was left to the Federal Government, faced with an unprecedented drought in the Basin, to legislate for the Basin Plan.

It was always going to be very difficult to carry everyone with the changes, especially those who were to bear the brunt of the cuts.

The media played several roles. It reported on the release of the Guide. It reported some of the details of the Guide, but it largely concentrated on those people who thought they would be disadvantaged by it. There was far less reporting on those who saw benefits in the Plan.

But the media also played a pivotal role in shaping the debate.

In the year leading up to the release of the Guide, the irrigation community and the river basin towns grew increasingly anxious about the Basin Plan. The Aarhus Convention (UNECE 1998) states: 'sustainable development can be achieved only through the involvement of all stakeholders.' But instead of using the lead-up as a time to involve all stakeholders - to forge, in the words of the Aarhus Convention, 'a new kind of agreement' - the MDBA largely went 
into lock-down. At the point when communities were desperate for information from the Authority, journalists seeking to speak to key players at the Authority could get nothing other than 'no comment' - if that.

The irrigators and the towns that depended on them proved far more savvy in their use of the media than the MDBA. They took full advantage of the Authority's silence.

In the week leading up to the release of the Guide, the media ran prominent stories highlighting irrigators' fears, but the MDBA refused to respond until the official release of the Guide, at $4 \mathrm{pm}$ on a Friday-late in the news day and the news week, and an extremely difficult time to organise coverage for big weekend editions of the newspapers and for early evening television news bulletins.

The result was those opposed to the Plan - or at least fearful of what the consequences of the Plan might be - set the agenda. Over the following days, only a careful reader of the newspapers - with the exception of the Adelaide press - would have learned why the Plan had been formulated. The battle was lost before the Guide was even released.

The points the MDBA needed to make - the necessity to make the MurrayDarling Basin environmentally sustainable and to do that only through purchases of water from voluntary sellers, with perhaps one-third of that water already in hand - were unlikely to be heard, even if they had been made with the strength and clarity they required (which they were not).

The initial reporting of a story - whether it is fair or unfair, accurate or erroneous - usually frames the debate. Thus, the irrigators set the agenda, and the story developed a momentum that could not be halted or redirected by a quiet, reasonable speech from the Chairman about the commendable objectives of the Guide.

The media also thrives on stories about conflict. As the MDBA held often-heated meetings across the Basin, the Authority was cast as the opposition, instead of a partner in a democratic debate.

The average news story is less than 500 words long, and usually contains just one new idea. There is little room for detailed history or nuance. There has also been a decline in the number of specialist rural reporters who could have provided that history, and brought to bear a deeper understanding of the Plan on their reporting.

Griffith was arguably one of the towns most impacted by the Plan. To hold the second community session there instead of in a South Australian centre such as Murray Bridge, which largely welcomed the Plan, was a poor choice. The burning of the Guide outside the Griffith meeting set the tone for the coverage of the series of public meetings about the Plan. 
Whether the MDBA under the chairmanship of Craig Knowles can rescue the Plan remains to be seen. His main challenge is to get the communication of the Plan back on track, to correct the misconceptions and begin to engage the communities he must carry with him if the Plan is to succeed. He will also need to restore the reputation of the MDBA as a body open to genuine dialogue with basin stakeholders.

Knowles will need strong support from the highest level of government if he is to succeed. The Prime Minister has paid lip-service to the Plan. But imagine the difference it would have made if, on the day of the release of the Guide, she had argued it was a world-leading plan for a better Australia. If she had outlined a glowing vision of a much healthier Murray-Darling Basin, and pointed out all water acquisition would be voluntary and promised no-one and no community would be left behind, the outcome would arguably have been different.

Knowles has a successful track record in pushing through difficult changes in water management with the Water Sharing Plans in New South Wales. Dealing with water at the Commonwealth level, where the only real leverage is the environment, could prove a great deal more challenging, as Mike Taylor found.

If yet another attempt is going to be made to restore the Basin to environmental health, there will have to be a far more concerted effort to engage with the community, to genuinely include them in the process, and to keep talking to them.

This includes communicating with journalists. This means more than being available to journalists, though this would be a good start. And it does not mean bombarding them with piles of information, as useful as this might appear to be.

It means preparing information in a clear, brief and accessible manner, assuming the journalist knows nothing at all about the subject - which, when it comes to rural and science matters, is increasingly likely to be the case.

It also means having a clear time line, providing information so reporters have ample time before their deadlines to come to grips with the subject, to talk to a number of people and line up an appropriate picture story and even write a comment piece. This cannot be done in one and half hours late on Friday afternoon.

A successful launch of the Guide would have meant making the case that the MDBA was rescuing the Basin from environmental catastrophe. But the irrigators got in first, and the overwhelming story the media ran became the catastrophe about to be inflicted on them by the Authority. 


\section{References}

Akerman, P. 2010, 'Farmers say jobs will flow out with water', The Weekend Australian, 9-10 October 2010, p. 7.

Arup, T. 2010, 'Selling the farm to save the rivers', Sydney Morning Herald, 9-10 October 2010, p. 1 .

Australian Broadcasting Corporation (ABC) 2010a, 'Basin politics', The National Interest, ABC Radio National, 8 October 2010, <www.abc.net.au/rn/ nationalinterest/stories/2010/3033392.htm>

Australian Broadcasting Corporation (ABC) 2010b, 'Burke defends timing of plan', Lateline, ABC Television, 8 October 2010, <www.abc.net.au/news/ video/2010/10/08/3033742.htm>

Burke, A. 2010, Population and communities, Australian agenda, Transcript, Minister for Sustainability, Environment, and Water, 10 October 2010, Parliament House, Canberra.

Commonwealth of Australia 2007, Water Act 2007, No. 137(2007), Commonwealth Consolidated Acts, www.austlii.edu.au/au/legis/cth/consol_act/wa200783/

Coorey, P. 2011, 'A cosy number for a party mate or the right man for the job?', Sydney Morning Herald, 29 January 2011, <www.smh.com.au/environment/ water-issues/a-cosy-number-for-a-party-mate-or-the-right-man-for-the-job20110128-1a8dv.html>

Department of Sustainability, Environment, Water, Population and Communities 2008, Progress of Water Recovery under Restoring the Balance in the Murray-Darling Basin Program, September, Department of Sustainability, Environment, Water, Population and Communities, Australian Government, Canberra, <www.environment.gov.au/water/policy-programs/entitlementpurchasing/2008-09.html $>$

Farr, M. and Townsend, S. 2010, 'Blood from stone, river study puts environment ahead of food output', Daily Telegraph, 9 October 2010, p. 3.

Franklin, M. and Karvelas, P. 2010, 'Reality hits in Murray blueprint', The Weekend Australian, 9-10 October 2010, p. 1.

Harvey, M. 2010, 'Farmers pay high price to save Murray-Darling basin', Herald Sun, 9 October 2010, <www.heraldsun.com.au/news/victoria/farmers-payhigh-price-to-save-murray-darling-basin/story-e6frf7kx-1225936174055> 
Jopson, D. 2010, 'Redgum skeletons are stark, eerie sentinels', Sydney Morning Herald, 9-10 October 2010, p. 4.

Karvelas, P. 2010, 'Rice, cotton farmers hardest hit', The Weekend Australian, 9-10 October 2010, p. 6.

Kelly, J. and Massola, J. 2010, 'Basin authority Mike Taylor's resignation won't halt Murray-Darling water reforms, says $\mathrm{PM}^{\prime}$, The Australian, 7 December 2010, <www.theaustralian.com.au/news/murray-darling-basin-boss-miketaylor-resigns/story-e6frg6n6-1225966814825>

Kelton, G. 2010, 'River rescued but at a cost', The Advertiser, 9 October 2010, $<$ www.adelaidenow.com.au/news/in-depth/river-rescued-but-at-a-cost/ story-e6frebju-1225936203940>

Kenny, M. 2010, 'Murray-Darling Basin Authority head Mike Taylor quits', The Advertiser, 7 December 2010, <www.adelaidenow.com.au/news/ in-depth/murray-darling-basin-authority-head-mike-taylor-quits/storye6frebju-1225966827897>

Ker, P. and Arup, T. 2010, 'Murray-Darling set for minimum water return', The Age, 9 October 2010, <www.theage.com.au/victoria/murray-darling-set-forminimum-water-return/20101009-16c23.html >

Kirk, A. 2010, 'PM says water reform on track, despite resignation', $P M, \mathrm{ABC}$ Radio, 7 December 2010, <www.abc.net.au/worldtoday/content/2010/ s3086763.htm>

Kruger, P. 2011, 'Former Labor MP new Murray-Darling Basin Authority boss', PM, ABC Radio, 28 January 2011, <www.abc.net.au/pm/content/2011/s3124477.htm ?site $=$ rural \&microsite $=$ murraydarling \&section $=$ latest $\&$ date $=($ none $)>$

Lewis, S. 2011, 'Craig Knowles is ALP's old man river', Daily Telegraph, 29 January 2011, <www.dailytelegraph.com.au/news/nsw-act/craig-knowlesis-alps-old-man-river/story-e6freuzi-1225996432267>

Lloyd, G. 2010, 'Plans must stay true to use of scarce resources', The Weekend Australian, 9-10 October 2010, p. 6.

Martin, S. 2011, 'Cronyism cries greet river boss', The Advertiser, 29 January 2011, <www.adelaidenow.com.au/news/south-australia/former-labor-mptakes-murray-role/story-e6frea83-1225996035376>

Media Monitors 2010, Questions regarding the Murray-Darling Basin Plan, Transcript of press conference, 8 October 2010, Media Monitors, Canberra, $<$ http://thebasinplan.mdba.gov.au/> 
Morris, S. 2010a, 'Debate heats up in a fluid environment', Weekend Australian Financial Review, 9-10 October 2010, p. 9.

Morris, S. 2010b, 'Water cuts to cost 800 jobs, \$1bn at farm gate', Weekend Australian Financial Review, 9-10 October 2010, p. 3.

Murray-Darling Basin Authority (MDBA) 2010a, Guide to the proposed Basin Plan, Murray-Darling Basin Authority, Canberra, <http://thebasinplan. mdba.gov.au>

Murray-Darling Basin Authority (MDBA) 2010b, Plan for the Murray-Darling Basin-Role of authority chair, 7 December 2010, Murray-Darling Basin Authority, Canberra, <www.mdba.gov.au/files/Media-release-Role-ofAuthority-Chair_0.pdf>

Murray-Darling Basin Authority (MDBA) 2010c, River Murray weekly report for the week ending 8 September 2010, Murray-Darling Basin Authority, Canberra, <www.mdba.gov.au/files/weeklyreports/WR100917-RiverMurray-Operations-Weekly-Report-08-September-2010.pdf $>$

Murray-Darling Basin Authority (MDBA) 2010d, River Murray weekly report for the week ending 6 October 2010, Murray-Darling Basin Authority, Canberra, $<$ www.mdba.gov.au/files/weeklyreports/WR 101007-River-MurrayOperations-Weekly-Report-06-October-2010.pdf>

Murray-Darling Basin Authority (MDBA) 2011, Weekly report for the week ending 5 January 2011, Murray-Darling Basin Authority, Canberra, <www. mdba.gov.au/water/river_info/weekly_report_archive>

Myers, P. 2010, 'You can't pay to save the environment if rains fail', Sydney Morning Herald, 9-10 October 2010, p. 4.

National Climate Centre 2011, Special Climate Statement 24, Updated 25 January 2011, National Climate Centre, Bureau of Meteorology, Melbourne, <www. bom.gov.au/climate/current/statements/scs24b.pdf>

NSW Office of Water n.d., Water sharing plans, Office of Water, Government of New South Wales, Sydney, <www.water.nsw.gov.au/Water-management/ Water-sharing-plans/Water-sharing/default.aspx $>$

Owen, M. and Schliebs, M. 2010, 'Farmers fume over Murray-Darling cuts', The Australian, 7 October 2010, p. 1.

Productivity Commission 2010, Market Mechanisms for Recovering Water in the Murray-Darling Basin, March 2010, Productivity Commission, Melbourne, <www.pc.gov.au/projects/study/water-recovery/report>, p. 140. 
Rolfe, J. 2010, ‘Knockout blow', Daily Telegraph, 9 October 2010, p. 1.

Roy Morgan 2010, Readership estimates for Australia for the 12 months to June 2010, Press release, 20 October 2010, Roy Morgan, <www.roymorgan.com/ news/press-releases/2010/1145/>

Simons, M. 2010, 'It's the story of a generation, shape up, media', Crikey, 8 October 2010, <www.crikey.com.au/2010/10/08/simons-its-the-story-of-ageneration-shape-up-media/11/10/2010>

Sydney Morning Herald (SMH) 2010a, 'A river runs through it', Sydney Morning Herald, 9-10 October 2010, p. 1.

Sydney Morning Herald (SMH) 2010b, 'Murray-Darling plan sails on inland sea of trouble', Editorial, Sydney Morning Herald, 9-10 October 2010, p. 10.

The Australian 2010, 'The Murray-Darling is a crucial test for Labor', Editorial, The Australian, 11 October 2010, p. 15.

Todd, A. 2010, 'Christmas camping closed by rising River Murray', The Advertiser, 6 December 2010, <http://www.adelaidenow.com.au/news/south-australia/ river-murray-water-levels-rising/story-e6frea83-1225966640770>

Townsend, S. 2010, 'Stopping the flow would finish Glen', Daily Telegraph, 9 October 2010, p. 3.

United Nations Economic Commission of Europe (UNECE) 1998, Convention on Access to Information, Public Participation in Decision-Making and Access to Justice in Environmental Matters [Aarhus Convention], United Nations Economic Commission of Europe, Geneva, </www.unece.org/env/pp/>

Vasek, L. and Wilson, L. 2010, 'Plan will "save river, kill towns"', The Weekend Australian, 9-10 October 2010, p. 7.

Wilson, L. 2011, 'Gillard to push ahead with Murray-Darling Basin plan despite floods', The Australian, 6 January 2011, <www.theaustralian.com. au/national-affairs/gillard-to-push-ahead-with-murray-darling-basin-plandespite-floods/story-fn59niix-1225983012023>

Wilson, L. and Schliebs, M. 2010, “Huge cost" in returning water to MurrayDarling river system', The Australian, 8 October 2010, p. 1.

Wong, P. 2009, Speech by Minister for Climate Change, Energy Efficiency and Water, Senator Penny Wong, to Victorian Farmers' Federation Annual General Meeting, 11 June 2009, <www.climatechange.gov.au/en/minister/ previous/wong/2009/major-speeches/June/sp20090611.aspx > 